\title{
THE GLOBAL WILDLAND FIRE NETWORK: \\ A GLOBAL PROGRAMME FOR ENHANCING INTERNATIONAL COOPERATION IN WILDLAND FIRE MANAGEMENT AND PREPARATION OF AN INTERNATIONAL WILDLAND FIRE ACCORD
}

\author{
Johann G. Goldammer and Claudia Scholz \\ The Global Fire Monitoring Center (GFMC) \\ Fire Ecology Research Group, Max Planck Institute for Chemistry \\ c/o Freiburg University, Georges-Koehler-Allee 075 \\ 79110 Freiburg, Germany
}

\section{INTRODUCTION}

\section{Rationale for Setting up Regional Wildland Fire Networks}

In many vegetation types of the world, the application of fire in agriculture and pastoralism and the occurrence of natural wildfires (natural fire regimes) are established (sustainable) elements in traditional land-use systems, natural ecosystem processes and biogeochemical cycles. However, excessive application of fire associated with rapid demographic and land-use changes in some regions, leads to destruction of productivity, reduction of carrying capacity and biodiversity of the vegetation cover. In some ecosystems, e.g. in the tropical montane forests, lowland rain forests and in forest plantations, wildfires burning under extreme weather conditions have detrimental impacts on economies, human health and safety, with consequences which are comparable to the severity of other natural hazards. Climate variability, such as periodic extreme droughts and extremely wet periods caused by the El Niño-Southern Oscillation (ENSO) phenomenon and the associated La Niña episode, contribute to the severity of fire impacts. Fires are also leading to secondary natural disasters such as landslides and floods, downstream of fire-denuded landscapes.

Fire management strategies which include preparedness and early warning cannot be generalized due to the multidirectional and -dimensional effects of fire in the different vegetation types and the large variety of cultural, social, and economic factors influencing them.

However, unlike the majority of the geological and hydro-meteorological hazards, wildfires represent a natural but predominantly human-influenced hazard which can be predicted, controlled and, in many cases, prevented.

The current state of wildland fire science and atmospheric sciences research of the last two decades potentially provide sufficient knowledge for fire management decision support and development of policies affecting the occurrence and consequences of human-caused fires. However, in many countries or localities in Africa, the requisite knowledge is either lacking or is not readily accessible for developing adequate measures in fire policies and management.

In response to the strategic goals of the UN Convention on Combat of Desertification (CCD), Convention on Biological Diversity (CBD), and the UN Framework Convention on Climate Change (UNFCC), the Ramsar Convention on Wetlands the UN Forum on Forests (UNFF), the Millennium Declaration of the UN General Assembly, and the objectives of the work of the Global Fire Monitoring Center (GFMC) and the World Conservation Union (IUCN), the UN-ISDR Inter-Agency Task Force for Disaster Reduction in 2001 established a Working Group on Wildland Fire. This Working Group was coordinated by the GFMC.

One of the priority fields addressed by the Working Group on Wildland Fire was the establishment of, and operational procedures for, a global network of regional- to national-level focal points and network structures for early warning of wildland fire, fire monitoring and impact assessment, aimed at enhancing existing global fire monitoring capabilities and facilitation of international cooperation in fire management. 


\section{History, proposed Modus Operandi, Status and Visions for building the Regional Wildland Fire Networks}

History

In keeping with the work of the Working Group on "Fire and Related Environmental Hazards" established under the IDNDR programme on Early Warning, the presentations and recommendations of the IDNDR Programme Forum 1999, and in accordance with the Framework for the Implementation of the International Strategy for Disaster Reduction (ISDR), the World Conservation Union (IUCN) and its associated partner, the Global Fire Monitoring Centre (GFMC) as well as the UN-FAO/ECE/ILO Team of Specialists on Forest Fire, suggested, in 2000, to create an interagency "Working Group on Wildland Fire".

This proposal was in line with several declarations made in international conferences during the last five years and is intended to bring together both the technical members of the fire community and the authorities concerned with policy and national practices in wildland fire management to realise their common interests of fire risk management and disaster reduction at global scale. The Inter-Agency Task Force for Disaster Reduction (IATF) at its second meeting on 11 October 2000 agreed to establish the Working Group on Wildland Fire (Working Group 4 [WG-4]).

Through the Working Group it was envisaged to establish an interagency and inter-sectoral forum of UN and other international agencies and programmes, and mechanisms of information and task sharing in the field of reducing the negative impacts of fire on the environment and humanity.

One of the priority fields of activity to be addressed by WG-4 was:

- Establishment of, and operational procedures for, a global network of regional- to nationallevel focal points for early warning of wildland fire, fire monitoring and impact assessment, aimed at enhancing existing global fire monitoring capabilities and facilitating the functioning of a global fire management working programme or network.

At the $2^{\text {nd }}$ meeting of WG-4 (3-4 December 2001) it was decided to give priority to the establishment of the "Global Network of Regional Wildland Fire Networks".

It was aimed to build regional networks on existing formal or informal networks structures and initiatives. The "Global Wildland Fire Network" would consist of a set of Regional Networks that are in place or will be initiated during the process of formation. A regional network may consist of several subnets or cooperative activities, e.g. in wildland fire science, fire monitoring, early warning, management or policy development.

The envisaged timeframe for setting up the network was January $2002-$ July 2003 . The $3^{\text {rd }}$ Global Wildland Fire Conference and the International Wildland Fire Summit (Sydney, 3-6 and 8 October 2003) was used as a platform to convene representatives from regional networks.

The strategy agreed by the Summit ("Strategy for Future Development of International Cooperation in Wildland Fire Management") includes the following agreement:

"The Regional Wildland Fire Networks will be consolidated, developed and promoted through active networking in information sharing, capacity building, preparation of bilateral and multilateral agreements, etc. This process will be facilitated through regional Wildland Fire Conferences and Summits in cooperation with the International Liaison Committee and the UN-ISDR Working Group on Wildland Fire".

For details of the preparation and outcomes of the International Wildland Fire Summit see: http://www.fire.uni-freiburg.de/summit-2003/introduction.htm

At a side event of the International Wildland Fire Summit a meeting was held with the regional fire management groups mandated under the auspices of the UN (ISDR Working Group on Wildland Fire, ECE/FAO/ILO Team of Specialists on Forest Fire, Fire Management Working Group, FAO North American Forestry Commission [NAFC] and the Forest Fire Group of FAO Silva Mediterranea). This was the first joint meeting of the four UN groups. A key output of the joint meeting was the recommendation to maintain a body under the auspices of the UN to enable the 
international community to maintain a unifying platform for the UN and jointly with non-UN groups and agreements.

The recommendation to maintain an advisory body for the UN must be understood i.a.w. the constitution of the IATF and the expected lifetime of a Working Group of ca. two to three years. Following these rules of the IATF the Working Group 4 on Wildland Fire would finish its work by end of 2003 and transit to an active outreach programme, the Global Wildland Fire Network (GWFN). To support the work of the GWFN the IATF accepted the proposal to create a Wildland Fire Advisory Group (WFAG) under the auspices of the ISDR. The WFAG will represent an advisory body to the UN system aimed at providing technical, scientific and policy-supporting advice to the UN family through the International Strategy for Disaster Reduction (UN-ISDR) and the IATF, and acting as a liaison between the United Nations system, the Global Wildland Fire Network and its supporting partners. It is envisaged to call for participation and support from $\mathrm{UN}$ agencies and programmes, other international organizations, non-government organizations, notably the IUCN-TNC-WWF Global Fire Partnership, government agencies, inter-governmental institutions and agreements, civil society, academia, the International Liaison Committee (ILC) of the series of International Conferences on Wildland Fire and the Global Fire Monitoring Center (GFMC) (to act as convener and secretariat).

The Wildland Fire Advisory Group will

- provide technical, scientific and policy-supporting advice to the UN family through the International Strategy for Disaster Reduction (UN-ISDR) and the IATF, and

- act as a liaison between the United Nations system, the Global Wildland Fire Network and its supporting partners.

It is envisaged to work with supporting partners of the WFAG will be

- UN agencies and programmes

- UN conventions (notably UNCBD, UNCCD, UNFCCC, Ramsar)

- Collaborative Partnership of Forests (CPF) and the UN Forum on Forests (UNFF)

- Other international organizations

- Non-government organizations, e.g., the IUCN-TNC-WWF Global Fire Partnership

- Government agencies

- Inter-governmental institutions and agreements

- Civil society

- Academia

- International Liaison Committee (ILC) of the series of International Conferences on Wildland Fire

- Global Fire Monitoring Center (GFMC) acting as convener and secretariat

In the transition stage from WG-4 to the WFAG the GFMC is available to continue facilitating the dialogue and direct interaction between the partners involved. The GFMC continues to work within the IATF as a member and representative of civil society and will ensure the appropriate information from the Global Wildland Fire Network and advisory support required for the mandate of the IATF.

The "Draft Work Programme for the IATF for 2004" reflects the overall intent to work together in the Global Wildland Fire Network and the Wildland Fire Advisory Group. This draft programme included a table in which the outcomes and follow-up arrangements for the four Working Groups were summarized for discussion at the meeting (table 1). 
Table 1: Extract of the final version of the "Work Programme for the IATF for 2004" released by the ISDR Secretariat on 23 November 2003

\begin{tabular}{|l|l|l|}
\hline $\begin{array}{l}\text { WG focus } \\
\text { 2001-2003 }\end{array}$ & Outcome end of 2003 & Follow-up arrangements- 2004 \\
\hline $\begin{array}{l}\text { WG4: Wildland } \\
\text { Fire, chaired by: } \\
\text { Monitoring Fire } \\
\text { (GFMC) }\end{array}$ & $\begin{array}{l}\text { International dialogue on cross-cutting } \\
\text { wildland fire issues fostered at UN inter- } \\
\text { agency level and with international } \\
\text { organizations and civil society }\end{array}$ & $\begin{array}{l}\text { Formation of a Wildland Fire } \\
\text { Advisory Group under the auspices of } \\
\text { the ISDR-IATF and GFMC }\end{array}$ \\
& $\begin{array}{l}\text { Establishment of Regional Wildland Fire } \\
\text { Networks, including inter-regional } \\
\text { cooperation }\end{array}$ & $\begin{array}{l}\text { ISDR / IATF endorsement and support } \\
\text { of the Global Wildland Fire Network } \\
\text { (IATF information updates to be } \\
\text { provided) }\end{array}$ \\
& $\begin{array}{l}\text { GFMC-ISDR global wildland fire } \\
\text { information system, web portal and } \\
\text { pragmatic outreach to user community } \\
\text { consolidated (including dedicated journal } \\
\text { and book publications) } \\
\text { <www.gfmc.org> }\end{array}$ & $\begin{array}{l}\text { Cooperation with the ASEAN Center } \\
\text { for Emergency Response and Strategic } \\
\text { Planning for Environmental Disasters }\end{array}$ \\
& $\begin{array}{l}\text { Support of preparation, facilitation and } \\
\text { implementation of the first International } \\
\text { Wildland Fire Summit (October 2003), } \\
\text { including preparation of the Summit paper } \\
\text { Strategy for Future Development of } \\
\text { International Cooperation in Wildland Fire } \\
\text { Management }\end{array}$ & $\begin{array}{l}\text { ISDR / IATF endorsement of the } \\
\text { outcomes of the International } \\
\text { Wildland Fire Summit. Preparation of } \\
\text { a Global Wildland Fire Summit } \\
\text { under the auspices of the UN, i.a.w. } \\
\text { recommendations by the 2003 Summit } \\
\text { (tentatively in 2005-2006) }\end{array}$ \\
\hline
\end{tabular}

Proposed Modus Operandi

On behalf of the ISDR the Global Fire Monitoring Center (GFMC) is facilitating the establishment of the Global Wildland Fire Network by supporting the establishment of Regional Wildland Fire Networks and enhancing inter-regional communication and cooperation.

The GFMC will liaise with existing operational and proposed international networks, notably:

- FAO Forestry Department

- UN-mandated regional teams (ISDR Wildland Fire Advisory Group, ECE/FAO/ILO Team of Specialists on Forest Fire, Fire Management Working Group of the FAO North American Forestry Commission (NAFC), Forest Fire Group of FAO Silva Mediterranea)

- Global Observation of Forest Cover - Global Observation of Landcover Dynamics (GOFC-GOLD) Fire Implementation Team (a subset of the Global Terrestrial Observing System - GTOS)

- Advisory Group on Environmental Emergencies (AGEE) and the Joint Environment Unit of the United Nations Office for the Coordination of Humanitarian Affairs (OCHA) and the United Nations Environment Programme (UNEP)

The Regional Wildland Fire Networks are encouraged to work with thematic networks that are in place or will be founded as independent or associated activities. A harmonization of objectives and efforts of independent networks is desired. The regional Fire Implementation Teams of the Global Observation of Forest Cover - Global Observation of Landcover Dynamics (GOFC-GOLD) will play a key role in the formation and operational functioning of the Wildland Fire Monitoring Networks (see: http://www.gofc-fire.umd.edu/). 


\section{Regional Coordination}

Regional Networks are formed in two ways. First, independent regional initiatives that were in place before 2001-2002 and after have been contacted and encouraged to become connected to the Global Wildland Fire Network. Second, a number of activities are being initiated in those regions where no such regional efforts are in place. The following information is taken from the website of the Global Wildland Fire Network:

http://www.fire.uni-freiburg.de/GlobalNetworks/globalNet.html

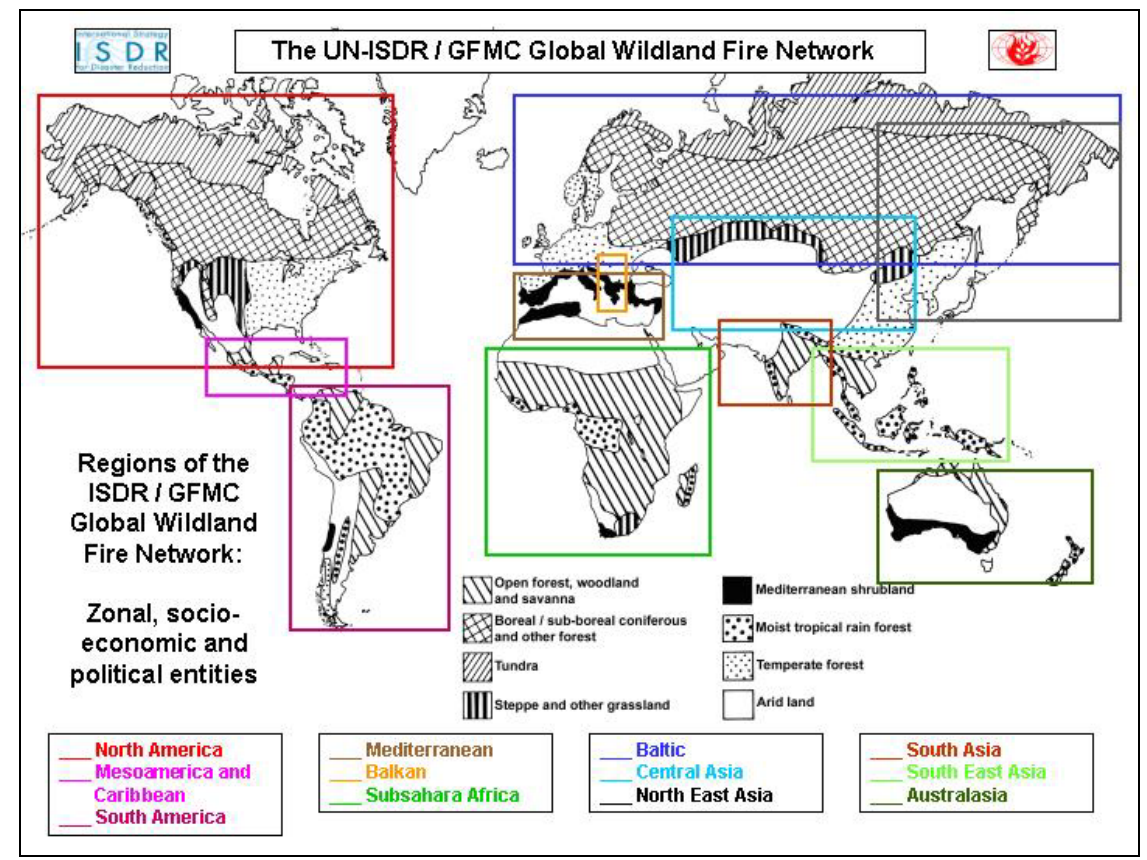

Figure 1: Delineation of regions within the Global Wildland Fire Network

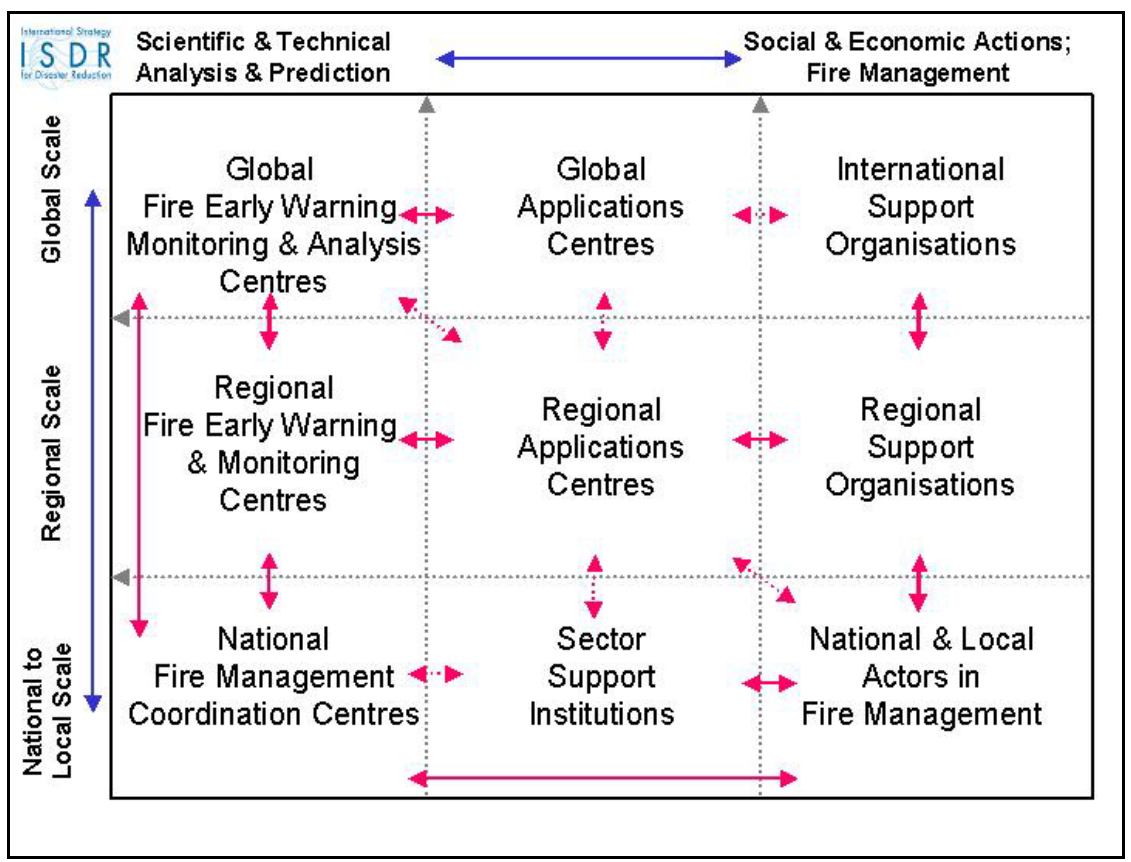

Figure 2: The role of the Global Wildland Fire Network in collection and dissemination of local to global wildland fire information for development of informed policy and decision support 


\section{Regional Subsahara Africa Wildland Fire Network}

The Regional Subsahara Wildland Fire Network ("Afrifirenet") was the first regional network that has been launched formally. On 3 July 2002 the network was kicked-off at its first official meeting held in the frame of the Wood for Africa Conference (Pietermaritzburg, South Africa). As of early 2004 more than 70 representatives from 13 African countries have registered as members of the network. The Subsahara Africa network coordinator is Mr. C. De Ronde, South Africa. An Advanced Wildland Fire Management Course (A Joint UN Inter-Agency Training Course with participation of UNEP, FAO and the United Nations University) for the SADC Region, sponsored by the German Foreign Office, Office for the Coordination of Humanitarian Assistance, has been held in Nelspruit, South Africa, 31 May - 5 June 2004. At the training course the Wildland Fire Management Training Handbook published by the GFMC was launched publicly. A website for the regional network has been established on the GFMC information system at:

http://www.fire.uni-freiburg.de/GlobalNetworks/Africa/Afrifirenet.html

\section{Regional South East Asia Wildland Fire Network}

At the World Conference on Land and Forest Fire Hazards (Kuala Lumpur, Malaysia, June 2002) two significant events paved the road for improving cooperation in fire management within the ASEAN (Association of South East Asian Nations) region and at international level. Building on almost a decade of cooperation in reducing the impacts of smoke-haze from land-use fires on the region the signing of the legally binding ASEAN Agreement on Transboundary Haze Pollution (10 June 2002; meanwhile ratified and entered into force on 25 November 2003) constitutes a multinational agreement for cooperation in fire management. At the ASEAN Senior Officials for Environment (ASOEN) Haze Technical Task Force meeting (10 June 2002) and the subsequent ASEAN Ministerial Meeting on Haze (11 June 2002) it was recommended that the ASEAN nations work together with the GFMC to establish a South East Asian Wildland Fire Network. The ASEAN Secretariat will serve as a regional network coordinator.

Starting in May 2003 the ASEAN Secretariat initiated the conceptual design of the South East Asia Fire and Haze Information Centre (other working title: ASEAN Center for Emergency Response and Strategic Planning for Environmental Disasters). This facility will largely take over the role of the network information system. The regional websites are:

ASEAN Haze Action Online Website: http://www.haze-online.or.id

GFMC Regional Website:

http://www.fire.uni-freiburg.de/GlobalNetworks/SouthEastAsia/ASEAN-FireNet.html

\section{Regional North East Asia Wildland Fire Network}

This network is currently being prepared and will include the participation of the Republic of Korea (South Korea), Democratic People's Republic of Korea (North Korea) (not yet confirmed), Japan and the Far East of the Russian Federation. During the International Wildland Fire Summit the representatives of the Republic of Korea have indicated a strong interest to support the formation of a regional node in South Korea. In November 2003 the Korean Forest Research Institute, Forest Fire Division, made its resources available to build the regional network. A kick-off meeting has been held in Seoul on 6 March 2004. Preliminary regional website in which the conference results will be presented (not finalized at the time of writing this manuscript):

http://www.fire.uni-freiburg.de/GlobalNetworks/Northeast-Asia/Northeastasia.html

\section{Regional Central Asia Wildland Fire Network}

Central Asia and its neighbour countries have recently suffered major forest and other wildland fire problems. The causes of an increasing occurrence of wildfires in forests and other wildlands, including the underlying reasons for increasing human-caused fires, vary within the region and are due to (1) the transition from centrally planned to market economies, (2) national to regional conflicts, creation of new nations, involving political tensions and war; (3) increasing population growth and land-use pressure, and (4) regional climate change involving an increasing occurrence of 
extreme droughts. The need has been recognized to initiate regional cooperation in wildland fire management, including wildland fire science. The "ECE/FAO International Conference on Management of Forest Fire Emergencies and International Cooperation in the Eastern Mediterranean, Balkans and adjoining Regions of the Near East and Central Asia" (Turkey, April 2004) provided an opportunity to clarify detailed objectives and modus operandi of the networking arrangement. The conference released the "Antalya Declaration on Cooperation in Wildland Fire Management in the Balkans, Eastern Mediterranean, Near East and Central Asia".

Provisional regional website:

http://www.fire.uni-freiburg.de/GlobalNetworks/CentralAsia/CentralAsia.html

Results of the Antalya Conference with Antalya Declaration:

http://www.fire.uni-freiburg.de/course/meeting/meet2004 05.htm

\section{Regional Australasia Wildland Fire Network}

In 1993 the Australian Fire Authorities Council (AFAC) was established to improve the collaboration and co-ordination of efforts between those Australian agencies with a responsibility for the protection of life and property from fire and other emergencies. The membership of agencies from the greater region saw AFAC's name change to the Australasian Fire Authorities Council in 1996. The current membership of AFAC stands at twenty-four full members and eleven associate members. All Australian fire and emergency agencies are full members of AFAC, as is the New Zealand Fire Service. Among the associate members are the Hong Kong Fire Service, Singapore Civil Defence Force and the Papua New Guinea Fire Service, while East Timor, Fiji, Samoa and Tonga are in the process of lodging applications under this membership category. AFAC aims to promote and coordinate activities in fire prevention, management and research through five Strategy Groups.

This regional arrangement offers the most suitable conditions for taking the lead in building the Regional Australasia Wildland Fire Network. This suggested arrangement has been discussed in March 2003 in Melbourne at the occasion of the meeting of the International Liaison Committee (ILC) of the $3^{\text {rd }}$ International Wildland Fire Conference and International Wildland Fire Summit. The proposal will be followed up by AFAC. For more details see:

AFAC Website: www.ausfire.com

GFMC Australasia Website:

http://www.fire.uni-freiburg.de/GlobalNetworks/Australasia/Australasia.html

\section{Regional Mediterranean Wildland Fire Network}

Following the discussions with FAO Silva Mediterranea in 2002 the formation of a Regional Mediterranean Wildland Fire Network is practically established under the auspices of this FAO group. A Workshop "Multilateral Assistance Against Forest Fires in the Mediterranean Basin" was held in Zaragoza, Spain, 10-11 June 2003. The objectives of the workshop included to study procedures to coordinate the existing mutual agreements and common legal and logistical tools to make effective, when needed, the multilateral assistance against forest fires within the Mediterranean Basin by sharing resources. A discussion was included about the possible role of the regional network and the GFMC to facilitate this process. The workshop was a preliminary activity to prepare a future Mediterranean conference on Multilateral Assistance against forest fires. Eastern Mediterranean countries participated at the "ECE/FAO International Conference on Management of Forest Fire Emergencies and International Cooperation in the Eastern Mediterranean, Balkans and adjoining Regions of the Near East and Central Asia" (Turkey, April 2004). The conference released the "Antalya Declaration on Cooperation in Wildland Fire Management in the Balkans, Eastern Mediterranean, Near East and Central Asia". For details see:

http://www.fire.uni-freiburg.de/GlobalNetworks/Mediterrania/Mediterrania.html

Results of the Antalya Conference with Antalya Declaration:

http://www.fire.uni-freiburg.de/course/meeting/meet2004_05.htm

The next regional event will be the an advanced seminar on "International Cooperation Programmes for Forest Fire Control in the Mediterranean Region" (Zaragoza, Spain, 27 September - 1 October 2004). For more information see: 
http://www.iamz.ciheam.org/ingles/incenfor-04-pub-ing.htm

\section{Regional Balkan Wildland Fire Network}

Within the Priority Area 4 "Environment Protection, Resource Management and Risk Prevention" of the EU INTERREG IIIB programme, Central Adriatic Danubian South-Eastern European Space (CADSES), an expression of interest for a project proposal has been initially discussed by the Global Fire Monitoring Center (GFMC) in June 2002 to promote cooperative transboundary wildland fire risk management and prevention of disasters under the proposed "South East European Fire Management Network" (SEEFIRE). Envisaged participating countries included Albania, Bosnia and Herzegovina, Bulgaria, Croatia, Hungary, the Former Yugoslav Republic of Macedonia, Romania, Serbia and Montenegro, and Slovenia.

The SEEFIRE Network intended to address the problem of wildland fires (forest fires and fires in other vegetation types) that are increasingly observed in the SE European transition countries. SEEFIRE would establish an interactive network of institutions of all countries listed below that are involved in the prevention and control of wildland fire. At the occasion of the International Scientific Conference "Fire and Emergency Safety During the XXI Century - The Course of Europe" (31 October - 1 November 2002, Sofia, Bulgaria) the GFMC proposed the network formation with representatives of the Balkan Region. Bulgaria has accepted to assist in building the network and liaise also to a number of Central Asian states.

A regional meeting of the International Commission for the Prevention and Extinction of Fires (CTIF) was convened in Bulgaria in February 2004 and discussed the establishment of a Regional Fire Monitoring Center. In March-April 2004 the "ECE/FAO International Conference on Management of Forest Fire Emergencies and International Cooperation in the Eastern Mediterranean, Balkans and adjoining Regions of the Near East and Central Asia" has been held in Turkey (for details: See Regional Central Asia Wildland Fire Network). The conference provided an opportunity to clarify detailed objectives and modus operandi of the networking arrangement. The conference released the "Antalya Declaration on Cooperation in Wildland Fire Management in the Balkans, Eastern Mediterranean, Near East and Central Asia". In the Antalya Declaration Bulgaria offered to host the Regional Fire Monitoring Center. A preliminary regional website is available at:

http://www.fire.uni-freiburg.de/GlobalNetworks/Balkan/Balkan.html

Results of the Antalya Conference with Antalya Declaration:

http://www.fire.uni-freiburg.de/course/meeting/meet2004 05.htm

\section{Regional Baltic Wildland Fire Network}

At the Baltic Exercise for Fire Information and Resources Exchange - BALTEX FIRE 2000 (Finland, June 2000) the UN ECE/ECE/ILO Team of Specialists on Forest Fires, through the Global Fire Monitoring Center (GFMC), initiated a communication and coordination process among the countries bordering the Baltic Basin. BALTEX FIRE 2000 was an initiative devoted to strengthen cooperation in forest fire management and transboundary cooperation in large fire disasters between all countries bordering the Baltic Sea. Participants were the nations bordering the Baltic Sea (Estonia, Finland, Germany, Latvia, Lithuania, Norway, Poland, Russia, Sweden) and neighbouring observer countries (Belarus, United Kingdom). The initiative is the starting point for the Regional Baltic Wildland Fire Network structures. On 10 May 2004 a Regional Baltic Wildland Fire Meeting was held in Finland (host: Ministry for Interior, Finland). The conference participants released the Helsinki Declaration on Cooperation in Wildland Fire Management in the Baltic Region. The regional website at the GFMC is:

http://www.fire.uni-freiburg.de/GlobalNetworks/BalticRegion/BalticRegion.html

\section{Regional Mesoamerica Wildland Fire Network}

Several recent developments indicate the political willingness of nations in Central America and Mexico to share information and resources in fire management. An important regional initiative has been launched by the First Central Mesoamerican Meeting on Forest Fire Protection (Primera Reunión Mesoamericana de Cooperación en Materia de Protección contra Incendios Forestales) held 
in Guatemala City, 8-9 July 2002. This regional meeting was organized in the frame of the project "Prevención y Combate de Incendios Forestales en Mesoamerica" of the "Programa Mesoamericano de Cooperación 2001-2002", launched at the occasion of the $4^{\text {th }}$ Tuxtla regional dialogue. Delegates of Belice, Costa Rica, El Salvador, Guatemala, Honduras, México, Nicaragua and Panamá participated in the meeting. The countries agreed formally to launch a programme of cooperation which includes sharing of information and resources in fire management as well as in capacity building. ${ }^{1}$

The Mesoamerica Meeting was followed by a meeting in Honduras (Taller para el Desarrollo de un Plan Estratégico Regional para el Manejo del Gorgojo del Pino y los Incendios Forestales en Centroamérica, 26-30 August 2002) in which the representatives from Central America developed a strategic plan for fire and bark beetle management in Central America. In 2004 the strategic plan has received financial support from US-AID and is currently in the project planning phase (June-July 2004). The momentum created by the Mesoamerican Meeting and the Honduras Strategy is currently coordinated with the Comisión Centroamericana de Ambiente y Desarollo (CCAD). Main actors are currently the Coordinador Nacional Protección Forestal del Instituto Nacional de Bosques (INAB), Guatemala; the Coordinador del Consejo Técnico del Sistema Nacional de Prevención y Control de Incendios Forestales (SIPECIF), Guatemala, and the Coordinador Nacional para el Manejo del Fuego del Sistema Nacional de Áreas de Conservación (SINAC) / Ministerio del Ambiente y Energía (MINAE), Costa Rica. At a regional meeting convened in Salvador, 8-9 July 2004, it was decided to designate a future network as Red Regional de Centro América y México de Incendios y Plagas Forestales operating under the CCAD. Decisions about future networking structures in which the previous networking efforts will be integrated will be made in August-September 2004.

Representatives from these organizations participated at the Foundation meeting of the Regional South America Wildland Fire Network (see next paragraph). A proposed timetable for further cooperative procedures between the three regions Central America, South America and the Caribbean is given below (not yet finally confirmed). All materials on the cooperative processes in the Mesoamerica Region are available at:

http://www.fire.uni-freiburg.de/GlobalNetworks/MesoAmerica/MesoAmerica.html

\section{Regional South America Wildland Fire Management Network}

Since the 1990s a number of regional initiatives have been underway in South America to enhance international cooperation in wildland fire research and management. The Brazilian National Space Research Institute (Instituto Nacional de Pesquisas Espaciais - INPE) and the Center for Weather Prediction and Climate Studies (Centro de Previsão de Tempo e Estudos Climáticos CPTEC) have expanded the domestic scope of work and product delivery. Since 2002 INPE is providing daily data on fire monitoring and fire-weather prediction specifically (detailed) for Brazil and Peru and in an overview format for all South American Countries.

In June 2004 representatives of South American countries met in Curitiba, Paraná, Brazil, to formally establish partnerships and a regional network to enhance international cooperation in wildland fire management. The foundation meeting of the network was held in conjunction with the $3^{\text {rd }}$ South American Symposium on Wildland Fire Control and the $7^{\text {th }}$ Joint Technical Meeting FUPEF/SIF/IPEF on Wildland Fire Control, 14-17 June 2004, Universidade Federal do Paraná, Curitiba, Brazil.

The foundation meeting was sponsored by the Global Wildland Fire Network (through GFMC), FAO, GOFC-GOLD, The Nature Conservancy (TNC) and the U.S. Forest Service. The recommendations of the Network Foundation Meeting will be presented to the participants of the Western Hemispheric Wildland Fire Conference, scheduled for 23 October 2004 in Costa Rica. This

\footnotetext{
${ }^{1}$ In June 2003 consultations were held with the Government of Guatemala concerning cooperation between the Mesoamerican Cooperation Regarding Protection against Forest Fires and the GFMC. A Memorandum of Understanding was signed by the Mesoamerican Permanent Technical Group on Forest Fires (Grupo Técnico Mesoamericano Permanente sobre Incendios Forestales), represented by the President of the Coordinating Council of the Sistema Nacional de Prevención y Control de Incendios Forestales (SIPECIF), Guatemala, and Executive Coordinator of the Presidency of Guatemala, and the Global Fire Monitoring Center (GFMC), UN International Strategy for Disaster Reduction (ISDR), Working Group on Wildland Fire, concerning Cooperation in the Global Wildland Fire Network through active participation of the Regional Mesoamerica Wildland Fire Network.
} 
conference will be a one-day side event of the joint meeting of the members of the FAO Forestry Commissions of North America and Latin America / Caribbean (for details: See Annex "Framework for the Development of the International Wildland Fire Accord"). Information concerning the progress of forming the South America Wildland Fire Network is available on the web:

http://pinho.floresta.ufpr.br/ firelab/

http://www.fire.uni-freiburg.de/GlobalNetworks/SouthAmerica/SouthAmerica.html

\section{Regional North America Wildland Fire Network}

Discussions about the formation and possible modus operandi of a Regional North America Wildland Fire Network are currently underway. The Fire Management Working Group (FMWG) of the North American Forestry Commission (NAFC) represents a regional network which will liaise North America's contribution to the Global Wildland Fire Network.

An initial proposal to formally join the Global Wildland Fire Network has been discussed in March 2003 in Melbourne at the occasion of the meeting of the International Liaison Committee (ILC) of the $3^{\text {rd }}$ International Wildland Fire Conference and International Wildland Fire Summit. The proposal has been followed up by the Fire Management Study Group (FMSG) in January 2004. For details on the Fire Management Study Group of the North American Forestry Commission see: http://www.fs.fed.us/global/nafc/fire/aboutus.htm http://www.fire.uni-freiburg.de/GlobalNetworks/NorthAmerica/NorthAmerica.html

\section{Regional South Asia Wildland Fire Network}

This network is currently under construction and most likely will include India, Bangladesh, Nepal, Bhutan and Pakistan. The Dehradun Forest Research Institute, India, has indicated interest to serve as a coordinating unit. Nepal has indicated interest to support the network.

\section{SUMMARY AND OUTLOOK}

The countries participating at the foundation meeting of the Regional South America Wildland Fire Network agreed to formally establish partnerships and a regional network to enhance international cooperation in wildland fire management. At the time of writing this paper the process of formation of the Regional Wildland Fire Networks in Central America and the Caribbean is also underway.

The next step will be the Western Hemispheric Wildland Fire Conference, scheduled for 23 October 2004 in Costa Rica. Together with the resolutions of consultations of the Regional Wildland Fire Networks during 2004 (see Annex) the results of the hemispheric consultation will prepare the ground for the ministerial-level conference in March 2005. It is expected that this high-level consultation will result in an expression of consensus to promote the idea of an International Wildland Fire Accord aimed at reducing the negative impacts of fire on the global environment and promote the wise and beneficial use of fire to maintain the role of fire to sustain biodiversity, stability and productivity of ecosystems. 
The global wildland...

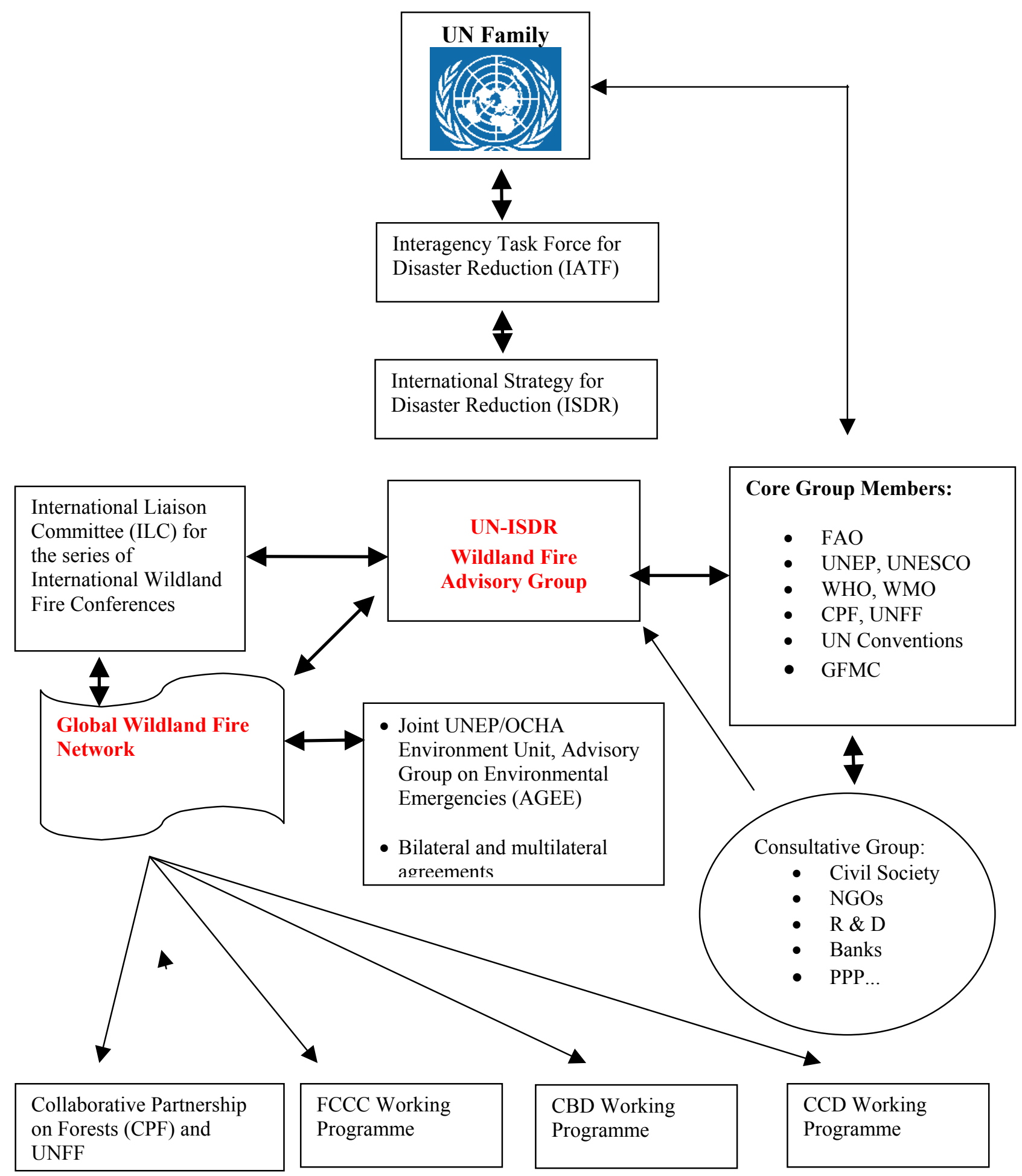

Figure 3. Draft scheme of cooperative relationships between the Wildland Fire Advisory Group, the Global Wildland Fire Network und the International Liaison Committee of the series of International Wildland Fire 


\title{
ANNEX \\ FRAMEWORK FOR THE DEVELOPMENT OF THE INTERNATIONAL WILDLAND FIRE ACCORD
}

\author{
Rationale, Status and Future Activities
}

Date: 1 May 2004, Update: 22 June 2004

Authors: Global Fire Monitoring Center (GFMC) in cooperation with FAO, ISDR and GOFC/GOLD

\section{INTRODUCTION: PURPOSE OF THIS DOCUMENT}

Over the past decade a growing trend of excessive fire application in land-use systems and land-use change, and occurrence of wildfires of extreme severities has been observed in many regions of the world. Some of the effects of wildland fires are of transboundary nature, e.g. the consequences of smoke pollution on human health and safety, loss biodiversity, or consequences of destabilization at landscape level leading to desertification or flooding at transnational scale. The depletion of terrestrial carbon by fires burning under extreme conditions in some vegetation types, including organic terrain in peatland biomes, is one of the driving agents of disturbance of global biogeochemical cycles, notably the global carbon cycle. This trend is calling the international community to commonly address this problem. The development of informal partnerships, joint projects and formal agreements between government and non-government institutions are essential to enable nations to develop sustainable fire management capabilities. United Nations agencies, programmes and conventions, as well as governments and civil society are calling for developing synergies aimed at enhancing efficiency and international cooperation in wildland fire management. This paper proposes the development of an International Wildland Fire Accord to reinforce and strengthen international cooperation in wildland fire management.

This Paper provides

- a brief global situation assessment (including an annex with references)

- a list of major international actors involved in, or having expressed the intent of support, building an international alliance (UN, non-UN international organizations, NGOs, science community, civil society, and governments) to address global wildland fire problems

- a list of major international events up to 2004 manifesting the interests of the international community

- framework and activities to support the development of the International Wildland Fire Accord (2004-2005)

\section{RATIONALE: GLOBAL WILDLAND FIRE STATUS AND TRENDS}

Between the mid 1990s and 2004 significant changes have been noted in the occurrence and impacts of wildland fire in some regions of the world:

- Extended droughts triggered by the El Niño - Southern Oscillation (ENSO) phenomenon first experienced in Indonesia in 1983 and again in 1997-98 favoured excessive application of fire in land-use change and occurrence of large wildfires in the tropics, resulting in above-average emission pulses of greenhouse gases and near-ground smoke pollution affecting human health and security.

- Uncontrollable wildfires in the USA between 2000 and 2003 are considered to be a consequence of earlier fire exclusion policies and regional climate change.

- The CIS countries and other countries in transition suffered institutional shortcomings which resulted in widespread wildfires, particularly in the Russian Federation, the Balkans and Central Asia. 
- Radioactive emissions from fires burning in forests contaminated by the Chernobyl disaster and other nuclear accidents in the Ukraine, the Russian Federation and Belarus continue to constitute a high threat to human health and security.

- Abandonment of the rural space in the Southern European countries involves less intensive utilization of vegetation biomass, thus resulting in increasing severities of fires with subsequent land degradation and secondary disasters.

- Increasing vulnerability of residential areas at the wildland-urban interface has been noted in North America and Australia where wildfires in the past decade have cause extremely high economic losses.

- The international community has responded to the increasing destructivity of wildland fires around the globe by drafting protocols, agreement guidelines and common terminology for enhancing international cooperation in wildland fire management.

- The Global Fire Monitoring Center (GFMC) and the FAO are instrumental to facilitate cooperative efforts and support UN policies through the ISDR Global Wildland Fire Network and the ISDR Wildland Fire Advisory Group.

Summary of global wildland fire trends:

- Trends are determined by local to national socio-economic and political developments; needs have emerged to integrate fire management with the aim of distributing management responsibilities from governments to local populations

- Globalisation of markets determine fire use and fuel loads

- Increasing fire severity observed in many regions as a consequence of coupled direct and indirect impacts of human interference and environmental change

- Other regions experiencing the consequences of fire suppression or reduced fire use, with consequences on biodiversity, carrying capacity, landscape patterns, etc.

- Alarming trend of fire-induced carbon transfer from the terrestrial sphere to the atmosphere, especially from drained or climatically altered wetlands

\section{FORMATION OF THE GLOBAL WILDLAND FIRE ALLIANCE TOWARDS THE DEVELOPMENT OF AN INTERNATIONAL WILDLAND FIRE ACCORD}

In the following the most important international organizations, institutions and other entities are listed that are currently contributing (or recently have contributed) to promoting the agenda of cooperation in the wildland fire arena at international level.

\section{Facilitation}

- Global Fire Monitoring Center (GFMC): Founded in 1998; support of UN institutions through its host institution (Fire Ecology Research Group) since the late 1980s, coordinating the facilitation through membership and mandate of:

- UN International Strategy for Disaster Reduction (UN-ISDR): Working Group on Wildland Fire (2001-2003) and UN-ISDR Wildland Fire Advisory Group (since 2004), serving as inter-agency advisory body to the UN (chaired by the GFMC)

- Global Wildland Fire Network: Programme facilitated by the GFMC, as an interagency programme of the ISDR, funded by the German government and FAO

\section{United Nations agencies, programmes and conventions mandated to address wildland fire}

- FAO: Promotion of international cooperation in wildland fire management; technical cooperation programmes (TCP) in the field, and information dissemination through seven Regional Forest Commissions; Global Forest Fire Assessments (FRA 2000 and 2005) jointly with GFMC; Fire Management Guidelines for Temperate and Boreal Forests jointly with GFMC; Wildland Fire Management Terminology update jointly with GFMC, promotion of Community-Based Fire Management (CBFiM); information dissemination and international documentation with global reactivation since 1998.

- Regional teams of wildland fire experts:

- ECE / FAO / ILO Team of Specialists on Forest Fire 
- North American Forestry Commission, Fire Management Working Group

- FAO Silva Mediterranea, Forest Fire Working Group

- WHO: Development of Health Guidelines for Vegetation Fire Events (currently no active position)

- WMO: Early warning of El Niño, fire weather, smoke transport

- UNESCO: Disaster reduction programmes (currently no specific programme)

- UNEP/OCHA: Joint UNEP/OCHA Environment Unit; Advisory Group on Environmental Emergencies (AGEE), WSSD Type II Partnership on Environmental Emergencies (GFMC member, FAO maintaining a Fire Alert Web Page to relay national fire emergency requests)

- ITTO: Guidelines for Fire Management in Tropical Forests, support of national fire management programmes, including CBFiM

- UNU: Establishment of the Institute for Environment and Human Security (2004), with wildland fire module (first UN inter-agency activity in 2004: Joint GFMC / ISDR / FAO / OCHA / UNU / NEPAD Advanced Wildland Fire Management Training Workshop for SADC Countries)

- UN Conventions: Agreement with the secretariats of the three Rio Conventions on cooperation with GFMC/ISDR, at the Workshop "Forests and Forest Ecosystems: Promoting Synergy in the Implementation of the Three Rio Conventions" (Viterbo, April 2004)

- Convention on Biodiversity (CBD): Member of the ISDR-IATF Wildland Fire Advisory Group (since2003)

- Convention on Combat of Desertification (CCD): collaborative arrangement with GFMC started in 2004

- Framework Convention of Climate change (FCCC): collaborative arrangement with GFMC started in 2004

- UN Forum on Forests (UNFF): Member of the ISDR-IATF Wildland Fire Advisory Group (since 2003)

\section{Non-Governmental Organizations}

- IUCN-TNC-WWF: Global Fire Partnership founded in September 2003; strategic meeting with international participation (May 2004)International Technical Committee for the Prevention and Extinction of Fire (Comité Technique International de Prévention et d'Extinction du Feu - CTIF): Reactivation of the Commission on Forest Fires (September 2003), First Conference: Experiences from 2002-2003 Wildland Fire Seasons: Are we prepared for the challenges ahead? (Austria, October 2003); Development of a Forest Fire Control Handbook for European Fire Services (by GFMC)

- Global Observation of Forest and Land Cover Dynamics (GOFC/GOLD) Fire Monitoring and Mapping Implementation Team: Global Forest Fire Assessment by spaceborne assets (to be involved in FRA 2005)

\section{PRECURSOR ACTIVITIES TO SUPPORT THE INTERNATIONAL WILDLAND FIRE ACCORD (BEFORE 2004)}

- International Decade of Natural Disaster Reduction (IDNDR): The decade (1990s) promoted synergies between international groups and entrusted the GFMC to coordinate the programme "Early Warning of Wildland Fire and Related Hazards"

- ECE/FAO Conference Forest, Fire and Global Change (Russian Federation, 1996): Elaboration of a proposal for international cooperation in wildland fire management

- FAO Consultations on Public Policies and Cooperation $(1998,2001)$

- International Wildland Fire Conferences in Vancouver (1997) and Sydney (2003)

- International Wildland Fire Summit (2003): Agreement on principles, international strategies and participatory fire management 


\section{FRAMEWORK AND ACTIVITIES TO SUPPORT THE INTERNATIONAL WILDLAND FIRE ACCORD (2004-2005)}

In 2004 international cooperation is addressed by a number of regional conferences and consultations:

- Northeast Asia (Korea, March 2004): Foundation of the Regional Northeast Asia Wildland Fire Network, hosted by the Korean Forest Service

- ECE/FAO conference on Cooperation in Wildland Fire Management in the Eastern Mediterranean, Near East, Balkans, Central Asia (Turkey, 30 March - 2 April 2004): Consolidation of the Regional Wildland Fire Networks for the Balkans, Eastern Mediterranean / Near East, Western and Central Asia, hosted by the Forest Service of Turkey (see "Antalya Declaration on Cooperation in Wildland Fire Management in the Balkans, Eastern Mediterranean, Near East and Central Asia"); Turkey to host a Regional Wildland Fire Advisory Group, and Bulgaria to host the Balkans Network.

- Baltic Region (Finland, May 2004): Regional Baltic Wildland Fire Meeting (follow-up to ECE/FAO BALTEX FIRE 2000), hosted by the Ministry for Interior, Finland; consolidation of the Regional Baltic Wildland Fire Network and the regional work of the ECE/FAO Team of Specialists on Forest Fire

- South America (Brazil, June 2004): Foundation of the Regional South America Wildland Fire Network, meeting hosted by the University of Paraná, Curitiba, co-sponsored by FAO, GFMC, USFS, UNEP, TNC and others

- Central America (July-September 2004): Consolidation of cooperation arrangements in Central America (CCAD/CCAB, Mesoamerica Agreement, Implementation of the Honduras Strategy)Foundation of the Regional Caribbean Wildland Fire Network (planned for September 2004, Cuba)Joint meeting of the Regional Wildland Fire Networks of South America, Central America, Caribbean, and North America (NAFC Fire Management Working Group) in preparation of the Western Hemispheric Wildland Fire Conference (Costa Rica, 2122 October 2004)Furthermore the following international consultations will be held in 2004-

- Western Hemispheric Wildland Fire Conference (Costa Rica, October 2004): Meeting of the FAO Regional Forestry Commissions of North America, Latin America and the Caribbean. Objective (among other): endorsement of the regional networking concepts prepared in Brazil and Costa Rica; recommendation for the ministerial meeting 2005.

- UN World Conference on Disaster Reduction (Japan, January 2005): The conference will review the Yokohama Strategy and Plan of Action (of 1994), including its wildland fire component, define WSSD-related specific activities and provide an inter-governmental platform to adopt an agenda for the frame 2005-2015. Global Wildland Fire Network and UNISDR Wildland Fire Advisory Group to contribute and seek an endorsable statement for the FAO Committee on Forestry (March 2005).

- High-level meeting at FAO Committee on Forestry (Rome, March 2005): Representatives of agencies and / or ministers responsible for forestry endorse a proposal directed to the United Nations concerning a coordinated effort in international cooperation in wildland fire management. Mid-term goal: UN General Assembly Resolution on Cooperation in Wildland Fire ManagementWith the recommendations of FAO Committee on Forestry and a possible UN GA resolution, more in-depth consideration could be given to an International Wildland Fire Accord that would reinforce and strengthen international cooperation.

\section{REFERENCES}

Wildland Fire Advisory Group. 2003. Vegetation fires globally. An analysis for policy makers prepared for the (UN-ISDR Inter-Agency Task Force for Disaster Reduction and the International Wildland Fire Summit. ECE/FAO International Forest Fire News (IFFN) No. 29 
http://www.fire.unifreiburg.de/summit2003/Summit\%20Background\%20Paper\%20Global\%20Situatio n.pdf

Global Fire Monitoring Center (GFMC)

http://www.fire.uni-freiburg.de/

FAO Wildland Fire Websites and FAO Global Forest Fire Assessment 1990-2000

http://www.fire.uni-freiburg.de/programmes/un/fao/Wp55_eng.pdf

UN-ISDR Wildland Fire Advisory Group

http://www.unisdr.org/eng/task\%20force/tf-working-groups4-eng.htm

Global Wildland Fire Network

http://www.fire.uni-freiburg.de/GlobalNetworks/globalNet.html

International Wildland Fire Summit

http://www.fire.uni-freiburg.de/summit-2003/introduction.htm

ECE/FAO International Forest Fire News (IFFN)

http://www.fire.uni-freiburg.de/iffn/iffn.htm

Convention on Biological Diversity

http://www.fire.uni-freiburg.de/programmes/un/cbd.htm

Joint UNEP/OCHA Environment Unit / WSSD Partnership for Environmental Emergencies

http://www.reliefweb.int/ochaunep/

http://www.reliefweb.int/ochaunep/tools/wssd.htm

WHO: Health Guidelines on Vegetation Fire Events

http://www.who.int/docstore/peh/Vegetation_fires/vegetation_fires.htm

International Tropical Timber Organization (ITTO) Wildland Fire Websites

http://www.itto.or.jp/live/index.jsp

http://www.fire.uni-freiburg.de/programmes/itto/itto_start.htm

Global Observation of Forest Cover / Global Observation of Landcover Dynamics (GOFC/GOLD) Fire Mapping and Monitoring

http://gofc-fire.umd.edu/

Crutzen, P.J., and J.G. Goldammer (eds.) 1993. Fire in the environment: The ecological, atmospheric, and climatic importance of vegetation fires. Dahlem Workshop Reports. Environmental Sciences Research Report 13. John Wiley \& Sons, Chichester, 400 p.

Ahern, F., J.G. Goldammer, and C. Justice (eds.). 2001. Global and regional vegetation fire monitoring from space: Planning a coordinated international effort. SPB Academic Publishing bv, The Hague, The Netherlands, $302 \mathrm{p}$. 